\title{
DE NORDISKE KRIMINALISTFORENINGER ÅR 2002
}

I det følgende er en redegørelse for aktiviteter m.v. i det forløbne år i de Nordiske Kriminalistforeninger.

\section{Dansk Kriminalistforening}

Foreningens formand er direktør William Rentzmann og sekretær og kasserer er advokat Bjørn Høberg-Petersen. Bestyrelsen består endvidere af professor Flemming Balvig, professor Ulla Bondeson, landsdommer Hans Henrik Brydensholt, rigsadvokat Henning Fode, dommer Peter Garde, professor Vagn Greve, politimester Lars Rand Jensen, overlæge Peter Kramp, forskningschef Britta Kyvsgaard, professor Gorm Toftegaard Nielsen, departementschef Michael Lunn og landsdommer Ina Steincke. Foreningens æresmedlemmer er højesteretssagfører Jon Palle Buhl og professor, dr. jur. Knud Waaben.

Årsmødet i foreningen fandt sted den 6. februar 2002. Efter generalforsamlingen holdt ph.d.-stipendiat (nu ph.d.) Thomas Elholm oplæg om EU's harmonisering af strafferetten.

Dansk Kriminologisk Selskab, der er et datterselskab til Dansk Kriminalistforening, arrangerede i foråret 2002 tre møder. Den 13. marts talte professor Henning Koch om Politikommissionens arbejde, og den 17. april indledte ph.d. studerende Niels Patrick Gosden om psykisk sygdom blandt unge kriminelle en status blandt 15-17 årige varetægtsfængslede og 9 års opfølgning af 15-19 årige kriminelle. Ved sidste møde $\mathrm{i}$ foråret den 15. maj talte sociolog Claus Lautrup om ungdomsprostitution - en evaluering af loven, som kriminaliserer prostitutionskunder til prostituerede under 18 år.

I efteråret var der to møder i selskabet. Vicedirektør Annette Esdorf redegjorde den 22. oktober for en ny udvalgsbetænkning fra Kriminalforsorgen om indsattes beskæftigelse og behandling, og professor Flemming Balvig og ph.d. Lars Holmberg holdt den 27. november et oplæg om erfaringer fra 6 forsøg med nærpoliti i Danmark.

Dansk Selskab for International Strafferet og EU-ret, der også er et datterselskab til Dansk Kriminalistforening, afholdt et seminar den 2. maj om antiterrorlovgivning med oplæg fra lektor Birthe Hansen, lektor Ole Spiermann, afdelingschef Lars Bay Larsen og professor Gorm Toftegaard Nielsen.

Derudover afholdt selskabet i efteråret møde den 16. september, hvor kommitteret Jakob Scharf holdt oplæg om det danske EU-formandskab og det politimæssige og strafferetlige område.

Dansk Kriminalistforeningen har desuden to provinsafdelinger, én på Fyn og én i Århus.

Ved årets udgang havde foreningen 529 medlemmer. 


\section{Kriminalistföreningen i Finland - Suomen Kriminalistiyhdistys}

Föreningens styrelse har under året 2002 haft följande sammansättning: Professor Raimo Lahti har fungerat som föreningens ordförande, överdirektör Maija Kukkonen har fungerat som föreningens viceordförande, assistent Markus Löfman har fungerat som föreningens sekreterare och direktör Marjatta Kaijalainen som föreningens kassaförvaltare. Styrelsens övriga medlemmar har under året varit följande: lagstiftningsråd Kimmo Hakonen, statsåklagare Päivi Hirvelä, professor Pekka Koskinen, överläkare Kerstin Kronqvist, tingsdomare Matti Lahti, överlärare Matti Laine, justitieråd Liisa Mansikkamäki, professor Kimmo Nuotio, ledande häradsåklagare Antti Pihlajamäki, biträdande justitieombudsman Ilkka Rautio, överdirektör Markku Salminen, advokat Salme Sandström, konsultativ tjänsteman Tapani Sarvanti och generalsekreterare Hannu Takala.

Professor Inkeri Anttila och socialråd Kaarlo Helasvuo är hedersmedlemmar i föreningen.

Föreningens årsmöte hölls den 14 maj 2002 i Vetenskapernas hus. Huvudtemat vid årsmötet var "Justitieministeriet och kriminalpolitiken - En ny organisationsmodell och strategiplan". Regeringsråd Jarmo Littunen och överdirektör Maija Kukkonen kom med sina inlägg i ärendet.

Förutom årsmötet ordnade föreningen på våren den 25 mars 2002 i Vetenskapernas hus en diskussionskväll över ämnet "Den av justitieministeriet tillsatta kontraktvårdskommissionens förslag". Diskussionen inleddes av Kommissionens ordförande, hovrättslagman Varpu Lahti. Kommissionens medlemmar, verksamhetsledare Jukka Mäki och tingsdomare Matti Lahti kom därtill med sina förberedda inlägg $\mathrm{i}$ ärendet.

Föreningen ordnade på hösten den 14 oktober 2002 vid Helsingfors universitet en diskussion över ämnet "Fångantalet stiger - hur är det med brottsligheten?". Diskussionen inleddes av chefen för Rättspolitiska forskningsinstitutet, professor Tapio Lappi-Seppälä.

Föreningen ordnade därtill den 18 november 2002 i Vetenskapernas hus en diskussionskväll över ämnet "Miljöbrottens särdrag". Diskussionen inleddes av statsåklagare Matti Nissinen. Forskare Jaana Pennanen kom därtill med sitt förberedda inlägg $\mathrm{i}$ ärendet.

Vid årets slut hade föreningen 226 medlemmar.

\section{Kriminalistforeningen i Island}

Formanden for den Islandske Kriminalistforening er Thorsteinn A. Jónsson, generaldirektør i Fængselsstyrelsen.

Ved årets udgang var der 21 medlemmer i foreningen. 


\section{Norsk Kriminalistforening}

Formannen for den Norske Kriminalistforeningen er førstelagmann Nils Erik Lie, Borgarting lagmannsrett. Styret består for øvrig av avdelingsdirektør Toril M Øie (nestleder), førstestatsadvokat Inger Marie Sunde, advokat Ellen Holager Andenæs, professor Ulf Stridbeck, tingrettsdommer Wenche Fliflet Gjelsten (varamedlem) og seksjonssjef Paul Larsson (varamedlem). Foreningens sekretær er førstestatsadvokat Trond Eirik Schea, ØKOKRIM.

Foreningen avholdt årsmøte med påfølgende debattmøte 6. februar 2002. Tema for debatt var "Trenger vi nye politimetoder for å forebygge kriminalitet?". Innledere var politiinspektør Stein Vale, advokat Øystein Storrvik og førstestatsadvokat Lasse Quigstad.

Foreningen avholdt også, sammen med Den norske Advokatforening Oslo krets og Forsvarergruppen av 1977, et debattmøte 25. september 2002. Tema var "Straffelovkommisjonens delutredning VII (NOU 2002: 4) Ny straffelov: (1) Avkriminalisering av bruk av narkotika?, og (2) Strafferammer - opp, ned eller begge deler?". Innledere var Straffelovkommisjonens leder Einar Høgetveit, advokat Marte Svarstad Brodtkorb, statsadvokat Erik Førde og professor Nils Christie. Møtet fikk gledelig stor oppslutning; over 100 personer var tilstede.

Ved årets utgang var det 274 medlemmer i foreningen.

\section{Svenska Kriminalistföreningen}

Ordförande i föreningen är rättschefen Fredrik Wersäll. Övriga styrelseledamöter under året har varit justitierådet Dag Victor, hovrättslagmannen Martin Borgeke, rikspolischefen Sten Heckscher, riksåklagaren Klas Bergenstrand, advokaten Tomas Rothpfeffer, överläkaren Stefan Skagerberg, häkteschefen Lars-Åke Pettersson, överdirektören Ann-Marie Begler, lagmannen Lena Berke, kanslirådet Lotta Gustavson och universitetslektorn Petter Asp som ersatt professorn Hanns von Hofer. Adjungerade styrelseledamoten, rättssakkunnige Marie-Louise Ollén har fungerat som sekreterare och kassaförvaltare.

Ämnet vid årsmötet var "Psykisk störning, brott och ansvar. Nytt påföljdssystem för de psykiskt störda lagöverträdarna" med inledningsanförande av riksdagsledamoten Christel Anderberg, professorn i psykiatri Lars Jacobsson, professorn i praktisk filosofi Torbjörn Tännsjö, professorn i straffrätt Suzanne Wennberg och rikspolischefen Sten Heckscher.

Vid föreningens höstmöte var ämnet "Stora ekobrottmål - hopplösa företag?" med inledningsanförande av journalisten och författaren Gunnar Lindstedt, staffrättsdocenten Hans-Gunnar Axberger, chefsrådmannen Rolf Nöteberg, avdelningschefen vid Ekobrottsmyndigheten Gunnar Stetler och advokaten och f.d. riksdagsledamoten Rolf Åbjörnsson. Debattledare var Fredrik Wersäll.

Föreningen har under året vidare arrangerat två kriminalpolitiska pubar. Vid vårpuben talade åklagaren Marie Tuma om sina erfarenheter från sitt arbete vid 
FN-tribunalen i Haag. Vid höstpuben talade generaldirektören för kriminalvården Bertel Österdahl om sina visioner om framtidens kriminalvård. Vid mötet medverkade också ämnesrådet Anne Holm Gulati.

Vid årets slut hade föreningen 341 medlemmar. 